\title{
The Implementation of The Inclusive Education Service Program for Autistic Children
}

\author{
Murniyanti Ismail, Annisa Arif Ma'rifah \\ UIN Antasari \\ Banjarmasin, Indonesia \\ zentijkt@gmail.com
}

\begin{abstract}
This study illustrates the application of inclusive education service programs for children with autism in the natural resources center of TK Negeri Idaman Banjarbaru covering planning, implementation and evaluation. This research is a field research, a research that aims to plunge the field to explore and collect the needed data. This study used qualitative methods in descriptive form, which describes all the events and symptoms that appear at the time of study. The methods used to collect the data were observation, interviews and documentation.
\end{abstract}

Keywords-inclusive education,children with autism.

\section{INTRODUCTION}

Early childhood education is one form of education that focuses on laying the foundation for growth and development, namely: moral and religious development, physical development(fine and gross motor coordination), intelligence/cognitive (power of thought, creativity), social emotional (attitude and emotion) language and communication, according to the uniqueness and stages of development according to age groups [1]. Children have a variety of conditions, characteristics, and culture, so that it should be understood by many people around the child, such as: parents, teachers and the community. Children who have differences (physical, intellectual, social emotional, linguistic conditions, etc.) have the same rights in getting a decent education [2]. This is in accordance with the 1945 Act (amended) article 31 paragraph 1 which states that "Every citizen has the right to education. The government provides opportunities for all children to get education services without seeing any differences in children, one of which is through inclusion.

Inclusive education aims to provide the widest possible opportunity and realize a rewarding education program diversity, and not discriminatory to all students who have abnormalities (physical, emotional, mental, social) or have intelligence potential (special talents) to obtain quality education according to their needs and abilities [2]. The learning center model of BCCT (Beyond Centers and Circle Times)with the Center and Environment approach is an inclusive learning model, children are stimulated to actively do learning and play, as well as being the subject and focus of learning itself, educators function more as motivators and facilitators [3], [4], [5]. BCCT learning in TK Negeri Idaman Banjarbaru country combines children in general with children with special needs which has a lot of dynamics and diversity in its implementation both include the strategy of methods and media used in natural materials centers. Approach through natural materials helps children's creativity. The center of natural materials is made so that the sensorimotor organs of the child work to recognize, explore and discover knowledge or concepts related to objects that are around them. The focus of this research is how is the application of inclusive education service programs for children with autism in the centers of natural materials for the TK Negeri Idaman Banjarbaru group that includes : planning, implementation and evaluation ?

\section{LITERATURE REVIEW}

UNESCO defines inclusive education as an approach to finding ways to change the education system to remove barriers that prevent children from being fully involved in education. These obstacles can relate to ethnic background, gender, social status, poverty, disability and others. According to Stainback inclusive schools are schools that accommodate all children in the same class [6]. Schools provide education programs that are feasible, challenging, but adapted to the abilities and needs of each child as well as assistance and support that can be provided by teachers so that children succeed [2]. In the implementation of inclusive education there is a strategy or initial thinking of the teacher before managing the process of teaching and learning activities, methods or ways of presenting learning material conducted by educators so that learning processes occur in children in an effort to achieve goals, and media or teaching aids and tools learning that comes from the surrounding environment and utilizes used goods as a means of playing for children [2].

The legal basis for inclusive education is found in Article 1 of the Minister of National Education Regulation No. 70 of 2009 concerning Inclusive Education for Students Who Have Abnormalities and Have the Potential for Intelligence and / or Special Talent, stating that: "Inclusive Education is an educational system that provides opportunities to all students who have abnormalities and have the potential for intelligence and / or special talents to attend education or learning in an educational environment together with general students [2].

According to Heward, children with special needs are children with different special characteristics with special 
characteristics that are different from children in general without always showing mental, emotional or physical disabilities [7]. Children with special needs, need special methods, materials, services and equipment in order to achieve optimal development, because children with special learning needs will learn quickly and learn differently.

Like children with symptoms of autism, those who suffer from the symptoms of autism are often seen as someone who lives alone, as like living in theire own world and apart from the social contacts around them. Autism is a form of growth and development disorders, in the form of a set of symptoms due to certain neurological disorders that cause brain function not to work normally so that it affects growth and development, communication skills, and the ability of one's social interaction [8]. Symptoms of autism easy to seefrom the various characteristics including, speech disorder, social skills difficulties, developmental disorder, intelectual disability, empathetic and sympathetic disorder [7], [8].

There are several factors of children becoming autistic, such as genetic factors. Families with children with autism have a higher risk than normal family, prenatal, natal and post natal populations, early bleeding pregnancy, medicines, baby crying late, respiratory disorders and anemia, the biochemical and blood structures, the possibility of the high content of dopamine and upioid in the blood, and psychosocial theory, the rude relationship, weak bounding around mother and child, metal poisoning severe, heavy metal poisoning can occur in children who live near coal mines, gold etc. or heavy metal poisoning in food consumed by pregnant women, for example fish with high heavy metal content [9].

For the treatment of children with autism can be addressed through therapy, such as occupational and physical theraphy, occupational theraphy help the child to develop strength and coordination without the use of tools. Speech and behavior therapy, behavior and the development relates to habituation children with autism to be able to express his wishes in a reasonable manner, eliminating phobias sort of sensitivity to light or sound, up to monitor each child's development to be easily identified their potential, biomedical therapy, to prevent / reduce allergies and behavioral disorders of diet some foods which have been considered trigger the worse condition [8].

Inclusive education in the center of natural materials for children with autism approaches through natural material centers, namely zones or children's play areas that are equipped with a set of playgrounds that function as an environmental platform needed to support children's development in 3 types of play, namely sensory motor or functional play, play the role and play of development. The learning model is a center of learning approaches in the learning process is carried out in "circles" (circle times) and play centers. The circle is a time when the educator sits with the child in a circular position to provide a foothold for the child before and after playing. The center of play is a zone or playground for children which is equipped with a set of playgrounds that function as a circular footing needed to develop all the basic potential of students in various aspects of development in a balanced manner. Centers that are opened every day are adjusted to the number of groups in the class. Learning centered on the center is done thoroughly starting from the beginning of the activity to the end.Every center supports child development.

Through play in "Sentra Bahan Alam" give right opportunities for children to "mess around" but also gives children the opportunity to interact directly with various kinds of materials to support sensorimotor, self control, and science with the aim of providing opportunities to build with a variety of materials or with different ingredients, giving children the opportunity to get a rich sensorimotor experience, and build self- control to support the development of sensorimotor, support the liquid construction development stage (painting stage, playdough stage ), support children to learn the concept of science concepts, support children to be more in control, and strengthen fine motor skills. The "Sentra Bahan Alam" is filled with various play ingredients that come from nature, such as water, sand, rocks, leaves. Equipment to play in natural materials centers such as: playdough, finger painting , painting, rice, grain, sand and water, crayons, markers, paper for painting and drawing, brushes (various sizes, large, medium, small), and tools for measuring (spoons, glasses, bottles, jerry cans). Activities carried out in the center of natural materials include measuring, weighing, filling, and observing.

Law Number 20 of 2013 concerning the National Education System paves the way for children with special needs to get a decent education. The opportunity to taste the sweetness of education is part of the rights of children with special needs. With inclusive education, children with autism can feel formal education at school, they can play together even though they must be accompanied by a mentoring teacher [10], [11], [12]. Inclusive education teaches that diversity is beautiful as evidenced by the presence of children with autism in The "Sentra Bahan Alam" that carry out activities together with other children. The service of children with autism in the "Sentra Bahan Alam" is evidenced by the activities of special education teachers who invite children to try various types of new activities. The application of inclusive education programs provides services for children with autism such as providing more extra help and attention compared to children in general. With the presence of children with autism in the center of natural materials, helping children with autism to imagine, exploring natural materials in their environment, children can learn and know more about their environment, and can stimulate tactile (feel touch with other objects) autistic children.

\section{METHOD}

The type of this research is field research (field research) by raising the title "the application of inclusive education service programs for children with autism in the "Sentra Bahan Alam" group B TK Negeri Idaman Banjarbaru" which was carried out using a qualitative approach in descriptive form [13], [14]. Data collection techniques use observation, interview and documentation techniques, through this technique researchers get information. After the information obtained is enough, it will be edited, make a coding ( processing the results of the respondent's answer data), and interpretation data (existing data and clarifying it without changing the meaning of the data) [15], [16]. 
After the data collection technique is complete, then researchers do analysis data, a process of finding and compiling data obtained from interviews, field notes, and documentation systematically. Data is organized into certain categories, translated into units, synthesized, and arranged into patterns. Choosing important data and data to be studied, finally making conclusions so that it is easily understood by yourself and others .

\section{RESULT AND DISCUSSION}

This qualitative research was carried out in the Banjarbaru country which is located at JL.RO Ulin Loktabat Banjarbaru Selatan in 2014/2015 school year. The area of the school is around $2500 \mathrm{~m} 2$, the status of this school is the State with the school statistics number (NSS) 001156106001. The building in this school consists of 1 principal's office, 10 classrooms, 1 UKS room, 1 library, 2 halls, a warehouse, and teacher and student toilets. While other facilities are outdoor / outdoor playgrounds located on the back and side pages. The condition of the building and the location of the kindergarten in the country is wide-ranging and has good facilities. TK Negeri Idaman has 51 employees, and 2 children with autism in the B group "Sentra Bahan Alam" .

The application of inclusive education in pre-primary school is inseparable from various components that support the achievement of learning goals. The data show that inclusive education was applied to kindergarten learning in group B in TK Negeri Idaman. This is in accordance with the theory of the UNESCO, defining inclusive education an approach to finding ways to change the education system in order to remove obstacles that prevent children from being fully involved in education. These obstacles can relate to ethnic background, gender, social status, poverty, disability and others. Inclusive schools are schools that accommodate all children in the same class, schools provide educational programs that are feasible, challenging, but adapted to the abilities and needs of each child as well as assistance and support that can be provided by teachers so that children succeed, as stated by Stainback. In one of the inclusive environmental character schemes and friendly learning that learning must involve all students regardless of differences.

This fact is proven in the implementation of inclusive education in the kindergarten learning process of group B. In the implementation of learning in kindergarten group $B$ the teacher does not discriminate between students and provides opportunities for all students who have abnormalities and have the potential intelligence and / or special talents to attend education or learning in an educational environment together with students in general. This fact is in accordance with the legal basis of inclusive education Article 1 of the Minister of National Education Regulation No. 70 of 2009 concerning Inclusive Education for Students Who Have Abnormalities and Have the Potential of Intelligence and / or Special Talents.

All kinds of differences in students' backgrounds do not become obstacles for students to get education.Students are eligible to play and learn together in school. Appropriate education is needed so that it can accommodate all students in playing and learning.

Planned before starting teaching and learning activities such as the curriculum used by schools, making RPPH, and PPI for children with autism and other student with special needs. After the planning phase is carried out, it leads to the implementation stage which includes the strategies, methods and media used by the teacher.

For the implementation of activities in the "Sentra Bahan Alam" for children with autism, Learning in TK Negei Idaman Banjarbaru there are 6 activities, namely: activities in the yard, religious learning activities, resting activities, playing activities in the classroom, lunch activities, and closing activities. These activities become a series of lessons that have been prepared in accordance with the school program. The teacher conducts learning in accordance with the RPPH that has been made in advance.

All activities that have been arranged are carried out and developed by each teacher according to the needs of autistic children. In addition to activities in natural materials centers, children with autism and other ABK entered the source room every Thursday, in the children's source room trained independence as seen in the picture above, the child was trained to wear his own clothes.

The last stage is evaluation, Evaluation is carried out every day, teachers in Kindergarten countries always record everything that is done by children both children and children in general. The method of assessment conducted by the teacher in kindergarten is ideal through observations the teacher observes about the child's development during activities, through interviews when learning the teacher always asks starting from the child before going to bed until going to school through interviews conducted by the teacher to get data about children, through notes anecdote that is a note made by the teacher in the event of an unusual child doing in class, for example, the child said harshly to a friend, even though the previous child never spoke harshly, then the teacher made an assessment, through an assessment of the portfolio when the child was welcome to do activities in the center there was always good activity attached or writing their own name there, the teacher assesses the work of the child, the assessment through work is done when the child does the activity to demonstrate the singing dance and so on and the teacher assesses.

Assessment for children with autism is no different from children in general, what is different lies in the child's development and ability. If the child with autism on the previous day does not want to touch the ground, if the next meeting the child wants to touch the ground, the teacher evaluates by describing that the child with autism starts to hold the land.

Inclusive education in the "Sentra Bahan Alam" for children with autism approaches through natural material centers, namely zones or children's play areas that are equipped with a set of playgrounds that function as an environmental platform needed to support children's development in 3 types of play, namely sensory motor or functional play, play the role 
and play of development. The learning model is a center of learning approaches in the learning process is carried out in "circles" (circle times) and play centers [17][18]. The circle is a time when the educator sits with the child in a circular position to provide a foothold for the child before and after playing. The center of play is a zone or playground for children which is equipped with a set of playgrounds that function as a circular footing needed to develop all the basic potential of students in various aspects of development in a balanced manner. Centers that are opened every day are adjusted to the number of groups in the class. Learning centered on the center is done thoroughly starting from the beginning of the activity to the end.Every center supports child development.

Through play in "Sentra Bahan Alam" give right opportunities for children to "mess around"but also gives children the opportunity to interact directly with various kinds of materials to support sensorimotor, self control, and science with the aim of providing opportunities to build with a variety of materials or with different ingredients, giving children the opportunity to get a rich sensorimotor experience, and build self- control to support the development of sensorimotor, support the liquid construction development stage (painting stage, playdough stage ), support children to learn the concept of science concepts, support children to be more in control, and strengthen fine motor skills. The "Sentra Bahan Alam" is filled with various play ingredients that come from nature, such as water, sand, rocks, leaves. Equipment to play in natural materials centers such as: playdough, finger painting, painting, rice, grain, sand and water, crayons, markers, paper for painting and drawing, brushes (various sizes, large, medium, small), and tools for measuring (spoons, glasses, bottles, jerry cans). Activities carried out in the center of natural materials include measuring, weighing, filling, observing.

Law Number 20 of 2013 concerning the National Education System paves the way for children with special needs to get a decent education. The opportunity to taste the sweetness of education is part of the rights of children with special needs. With inclusive education, children with autism can feel formal education at school, they can play together even though they must be accompanied by a mentoring teacher [10]-[12]. Inclusive education teaches that diversity is beautiful as evidenced by the presence of children with autism in The "Sentra Bahan Alam" that carry out activities together with other children.The service of children with autism in the "Sentra Bahan Alam" is evidenced by the activities of special education teachers who invite children to try various types of new activities. The application of inclusive education programs provides services for children with autism such as providing more extra help and attention compared to children in general.With the presence of children with autism in the center of natural materials, helping children with autism to imagine, exploring natural materials in their environment, children can learn and know more about their environment, and can stimulate tactile (feel touch with other objects) autistic children.

\section{CONCLUSION}

Diversity is beautiful, all humans are created with the strength of the gan and the advantages of each.In this life we will find many differences such as differences in race, religion, ethnicity, physical, skin, language, ethnicity, culture, customs, differences in class, social status, and other differences. Any kind of difference that should not make us split, discriminate, racist or hate each other but still unite, respect, tolerance and help. Through inclusive education , children with autism can go to school and make friends with children in general regardless of deficiencies, there they do not get discriminatory.

\section{REFERENCES}

[1] S. Aisyah, Perkembangan dan Konsep Dasar Pengembangan Anak Usia Dini. Jakarta: Universitas Terbuka, 2012.

[2] I. Yuwono and U. Utomo, Pendidikan Inklusif Paradigma Pendidikan Ramah Anak. Banjarmasin: Pustaka Banua, 2015.

[3] F. Anjaryati, "Tesis Pendidikan Inklusif Dalam Pembelajaran Beyond Centers And Circle Times (BCCT) Di PAUD Inklusi Ahsanu Amala," UIN Kalijaga, Doctoral dissertation. Yogyakarta, 2011.

[4] L. Asmawati, "Perencanaan Pembelajaran PAUD." PT Remaja Rosdakarya, Bandung, 2014.

[5] M. Latif and dkk, Orientasi Baru Pendidikan Anak Usia Dini:Teoti dan. Jakarta: Kencana, 2013.

[6] W. Adiarti, "Pengaturan Ruang Kelas Untuk Inclusive Preschool (Studi Kasus di TK Al-Falah Ciracas Jakarta Timur)," J. Pendidik. Anak, vol. 1, no. 2, 2012.

[7] A. Murtie, Ensiklopedia Anak Berkebutuhan Khusus. Yogyakarta: Maxima, 2014.

[8] C. Sunu, Unlocking Autism. Yogyakarta: Lintang terbit, 2012.

[9] D. Lestari, Deteksi Penyakit Anak dan Pengobatannya. PT. Suka Buku. Jakarta: PT SUka Buku, 2012.

[10] A. C. Faradilla, "Skripsi Penerapan Pendidikan Inklusi Pada Pembelajaran Taman Kanak-Kanak Kelompok A (Studi Kasus Di Komino Playschool Yogyakarta)," Skripsi . Tidak dipublikasikan., Yogyakarta, 2013.

[11] D. Rachmayana, Diantara Pendidikan Luar Biasa Menuju Anak Masa Depan Yang Inklusif. Jakarta: Luxima, 2013.

[12] L. R. Anggraini, "Skripsi Proses pembelajaran inklusi untuk anak berkebutuhan khusus (ABK) kelas V SD Negeri Giwangan Yogyakarta," Skripsi. Tidak dipublikasikan, 2014.

[13] A. Hadi and H. Haryono, Metodologi Penelitian Pendidikan. Bandung: Pustaka Setia, 2005.

[14] A. Suharsimi, Metode Penelitian. Yogyakarta: Bina Aksara, 2006.

[15] S. Nasution, Metode Penelitian Naturalistik Kualitatif. Bandung: Tarsito, 2003.

[16] S. Sugiyono, Metode Penelitian Kuantitatif, Kualitatif dan R\&D. Bandung: Alfabeta, 2014.

[17] B. U. Hamzah, Uno: Model Pembelajaran Menciptakan Proses Belajar Mengajar yang Kreatif dan Efektif. Jakarta: Bumi Aksara, 2016.

[18] S. Abimanyu, Strategi pembelajaran 3 SKS. Banjarmasin: Direktorat Jenderal Pendidikan Departemen Pendidikan Nasional, 2009. 